\title{
Desert detritivory: Nutritional ecology of a dung beetle (Pachysoma glentoni) subsisting on plant litter in arid South African sand dunes
}

\author{
P. Holter ${ }^{\mathrm{a}, *}$, C.H. Scholtz ${ }^{\mathrm{b}}$, L. Stenseng ${ }^{\mathrm{a}}$ \\ ${ }^{a}$ Department of Terrestrial Ecology, Institute of Biology, University of Copenhagen, Øster Farimagsgade 2D, DK-1353 Copenhagen K, Denmark \\ ${ }^{\mathrm{b}}$ Department of Zoology and Entomology, University of Pretoria, Pretoria 0002, Republic of South Africa
}

\section{A R T I C L E I N F O}

\section{Article history:}

Received 12 February 2009

Received in revised form

3 April 2009

Accepted 15 April 2009

Available online $\mathrm{xxx}$

\section{Keywords:}

Assimilation

Desert detritus

Fungal biomass

Scarabaeidae

Water balance

\begin{abstract}
A B S T R A C T
Dry conditions limit microbial decomposition of plant litter in deserts, which leaves a primary role to detritivorous macroarthropods. In the sandy arid strip along the west coast of South Africa, such detritivores include the large scarabaeid dung beetle Pachysoma glentoni. Highly unusual among dung beetles, this species collects surface litter and drags it into an underground storage and feeding chamber which is abandoned after 6-7 days. Fresh stores for single beetles and for breeding pairs (mean depths: 30 and $39 \mathrm{~cm}$ ) contained about 1.1 and $2.9 \mathrm{~g}$ organic matter, respectively. Using ergosterol as a biomarker for fungal biomass, we tested the hypotheses that (1) the dry detritus takes up water underground; (2) this promotes fungal growth on the detritus, and (3) fungi are the main food of the beetles. These hypotheses were disproved, but the stored litter, including floral remains, was shown to have relatively high quality (mean atomic C:N ratio: 35 ) and the beetles assimilated about $60 \%$ of it. Estimated weekly water gain per beetle, supplied entirely by the food, was about $0.6 \mathrm{~g}$. Our results highlight unique nutritional adaptations to survival in deserts without the usual dung beetle food: wet dung of large herbivores.
\end{abstract}

(c) 2009 Elsevier Ltd. All rights reserved.

\section{Introduction}

Microbial decay of freshly fallen plant litter in arid ecosystems is severely limited by lack of water. An important, primary role in decomposition is therefore left to surface-active detritivorous macroarthropods (Noy-Meir, 1974; Louw and Seely, 1982; Ayal, 2007) which are often abundant in deserts (e.g. Louw and Seely, 1982; Crawford and Seely, 1987; Doblas-Miranda et al., 2007). Among the many taxa (reviewed by Crawford, 1981, 1991 and Louw and Seely, 1982), the beetle family Tenebrionidae is particularly important and diverse in the Namib ecosystem along the arid west coast of southern Africa. These beetles have been extensively studied by Seely (1979, 1983), Seely and Mitchell (1987), Crawford et al. (1990) and Hanrahan and Seely (1990). By contrast, little is known about the detritivorous members of the scarabaeid (subfamily: Scarabaeinae; tribe: Scarabaeini) genus Pachysoma MacLeay, large beetles which may be locally abundant in the southern Namib and then predominant among detritivores.

Whereas most Scarabaeini are flying and ball-rolling dung beetles feeding on moist, fresh dung, the 13 known Pachysoma

\footnotetext{
* Corresponding author. Tel.: +45 35 322175; fax: +45 35322321.

E-mail addresses: pholter@bio.ku.dk (P. Holter), chscholtz@zoology.up.ac.za (C.H. Scholtz), mail@stenseng-i.dk (L. Stenseng).
}

species are all flightless and have switched to drier kinds of food. According to Harrison et al. (2003), five of them feed mostly on dry faecal pellets of rodents, hares or small ruminants; wet, fresh dung is not accepted (Scholtz, 1989). A few forage on plant detritus only, and two are mixed feeders (pellets + detritus). The food of the remaining species is unknown.

The activity of Pachysoma species peaks in spring/early summer, i.e. October-December. Each foraging beetle excavates a tunnel leading to a storage chamber in the sand. Food is then collected on the sand surface, held by the hind legs and dragged forward to the burrow. Until recently, subsequent activity has only been observed for the pellet-feeding Pachysoma striatum (Scholtz, 1989). Food is first stored in a preliminary holding chamber at a depth of 40$50 \mathrm{~cm}$. The entrance to the burrow is blocked from inside with sand, and a deeper $(60-70 \mathrm{~cm})$ feeding chamber is constructed. The food is then moved to this chamber and the tunnel between chambers blocked. After about seven days the food seems depleted, and the beetle leaves the burrow to commence a new cycle of digging, collecting and feeding. Since the deep feeding chambers at Scholtz's (1989) site were in relatively moist sand, pellets were assumed to take up some water, which might soften them and make them more suitable as food. Underground feeding on surface detritus occurs in only a few groups of detritivores. Well-known examples are anecic earthworms (Bouché, 1977) and termites. 
The present study explores the nutritional ecology of adult Pachysoma glentoni that feed exclusively on plant litter. This is presumably a poorer diet than the wet dung eaten by most dung beetles (Holter and Scholtz, 2007) and is highly unusual food among adult Scarabaeinae. However, some scarabaeines eat fungi, probably a richer and less recalcitrant substrate (Pokarzhevskii et al., 2003; Pollierer et al., 2007). Indeed, Scholtz and Chown (1995) argued that fungi may be the ancestral adult food in Scarabaeidae. Inspired by this and the information about $P$. striatum we hypothesised that (1) the dry detritus absorbs water in the deep, humid storage and feeding chamber; (2) the increased moisture promotes fungal growth on the plant material, probably during a somewhat longer storage than one week; and (3) P. glentoni feeds, at least partly, on this fungal biomass. Alternatively (4), the beetles must feed on the detritus itself. These hypotheses were tested using ergosterol as a biomarker for total (living and dead) fungal biomass (Newell et al., 1988; Salmanowicz and Nylund, 1988; Clemmensen et al., 2006). Finally, we discuss $P$. glentoni's assimilation efficiency and possibilities of water gain.

\section{Materials and methods}

\subsection{Study site}

Field work was carried out in early October 2005 about $16 \mathrm{~km}$ southeast of Lamberts Bay on the west coast of South Africa $\left(32^{\circ} 13^{\prime} 06.3^{\prime \prime} \mathrm{S}, 18^{\circ} 26^{\prime} 06.8^{\prime \prime} \mathrm{E}\right)$. The annual, rather variable and unpredictable rainfall at Lamberts Bay (1986-2006) averages $165 \mathrm{~mm}$, mostly (mean: $102 \mathrm{~mm}$ ) in the winter months MayAugust. Hence, the region is arid according to the definition adopted by Louw and Seely (1982). However, cool, on-shore breezes from the sea lead to frequent nocturnal fog and relatively high air humidity, mean values for October at 08:00, 14:00 and 20:00 being 77,59 and $76 \%$, based on data for nine years in the period 1995-2006 (South African Weather Service).

The only larger mammals observed at the study site were hares (Lepus spp.). The sand is relatively firm, which P. glentoni seems to prefer (Harrison et al., 2003). The sparse vegetation is a mixture of dwarf bushes, grasses and several species of forbs, mainly belonging to the Mesembryanthemaceae, Asteraceae, Orobanchaceae, Liliaceae and Iridaceae. In spring, after good winter rains, these plants produce many flowers. P. glentoni was abundant and collected litter including many flower remains such as wilted sepals, petals and seeds. Foraging for one food store takes only a few hours, often distributed over a couple of days.

\subsection{Field and laboratory methods}

The day when a burrow was closed was noted as day 0 . Three to seven stores were excavated for each of the age-classes $0,1,2,3,5,6$ and 7 days. Each burrow had only one chamber, mostly vacated by the beetles by day 7 (Fig. 1). In total, 37 chambers were excavated within the period 09.00-16.00. After measurement of the depth of each chamber and the temperature of the sand surrounding it, the contents were collected in tight plastic bags. In four cases, larger samples of the sand around chambers were also taken to measure water content. Depths and weights of two very large stores from day 0 and 1 , probably collected by males for breeding, but still without females, were excluded from the means for single beetles and for those for pairs (see Section 3.1).

Each sample (including beetle faeces, mostly indistinguishable from other detritus) was shaken gently on a $1 \mathrm{~mm}$ mesh sieve, which removed most sand $(<1 \mathrm{~mm})$ from the detritus $(>1 \mathrm{~mm})$. About half of each detritus sample was weighed, dried

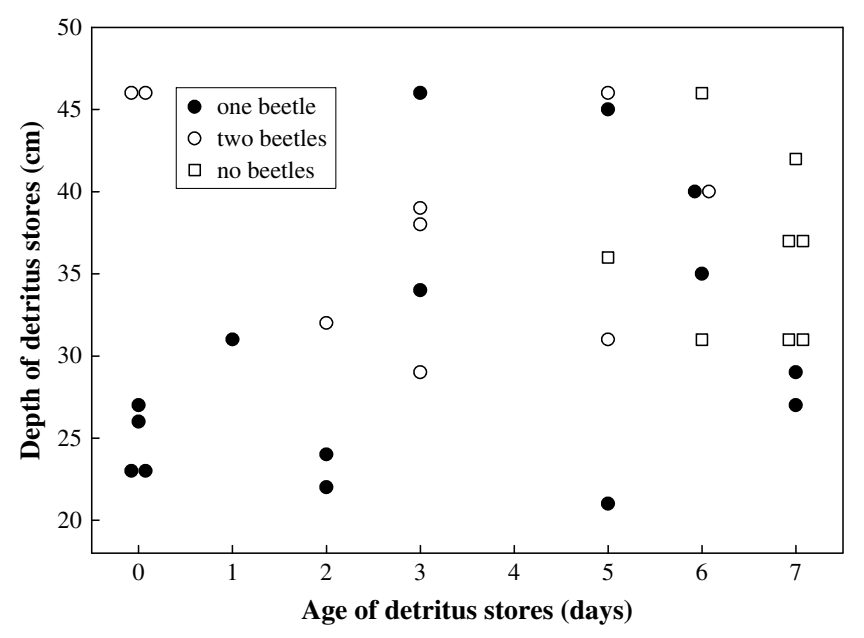

Fig. 1. Depth of detritus stores collected by Pachysoma glentoni in relation to store age (days since closure of burrow) and the number of beetles found in the storage chambers.

under a $60 \mathrm{~W}$ light bulb and kept in an air-tight plastic bag until determination of water, $\mathrm{C}, \mathrm{N}$ and organic matter (OM) contents (Fraction A). The remaining fraction (Fraction $\mathrm{B}$ ) was weighed and stored in the dark at $2-4{ }^{\circ} \mathrm{C}$ in a tightly closed $30 \mathrm{ml}$ vial with a known volume of $100 \%$ methanol which just covered the detritus. This storage prevented loss of ergosterol until analyses could be performed (Newell et al., 1988). Seven samples provided too small quantities of fractions A and B for the planned analyses and had to be pooled with other samples of the same age.

Fraction A of each sample and the four samples of pure sand were dried at $100{ }^{\circ} \mathrm{C}$ to constant weight to determine water content. Fraction A was ground in a mortar and thoroughly mixed, and the amount of $\mathrm{OM}$ in a subsample was measured as loss on ignition at $550{ }^{\circ} \mathrm{C}$. C and $\mathrm{N}$ contents were determined (TrueSpec CN Elemental Determinator, LECO ${ }^{\circledR}$ Corporation, St. Joseph, MI, USA) as mean values of three subsamples. Total water, OM, $\mathrm{C}$ and $\mathrm{N}$ in the original food store were then calculated. Carbon to nitrogen ratios were used to quantify nitrogen.

Ergosterol analyses (Fraction B) were performed as described by Clemmensen et al. (2006), but the procedure was scaled up to accommodate large samples comprising up to $25 \mathrm{ml}$ of methanol + detritus. Initially, each sample was transferred to a $45 \mathrm{ml}$ centrifuge vial, and the methanol content was increased to $25 \mathrm{ml}$. $\mathrm{KOH}$-pellets were added directly to provide a concentration of $10 \%$. The procedure of Clemmensen et al. (2006) was then followed with volumes of $\mathrm{H}_{2} \mathrm{O}$ and cyclohexane increased in proportion to the larger sample size. A total of $3 \mu \mathrm{g}$ ergosterol per mg fungal biomass was used as a conversion factor (Salmanowicz and Nylund, 1988).

\subsection{Statistical analyses}

General linear modelling (SAS 9.1; SAS Institute Inc., Cary, NC, USA) was used to assess the effect of, e.g. water contents or age of food stores on dependent variables such as fungal biomass. Where necessary, variables were log-transformed to stabilise variances and improve normality of the data. In cases where the choice was not obvious, the best significant $(P<0.05)$ model, i.e. the one that best fitted the data with fewest parameters, was chosen according to the Schwarz (BIC) criterion (SAS Mixed Procedure) recommended by Quinn and Keough (2002). 


\section{Results}

\subsection{Depth, temperature, weight and moisture of buried food stores}

At one corner of the site, the seemingly unselective beetles collected leaf litter and seed capsules from planted eucalypts. This material was apparently not eaten. Five stores excavated close to eucalypts were only included in the information on depth and temperature of storage chambers but not in that on weight, moisture, fungal biomass, $\mathrm{N}$ and $\mathrm{C}$.

The lack of any obvious trend towards deeper chambers with increasing age (Fig. 1) confirms the field observation that food was taken directly to the final storage chamber, without any preliminary holding chamber. All younger (age $<5$ days) food stores contained one or two beetles, in the latter case always a female and male, i.e. probably a breeding pair. The best model for the depth of chambers with beetles had beetle number (single/pair), age (day) and age $\times$ number as independent variables. Chambers with pairs were significantly $(P=0.013)$ deeper $(39 \pm 2.2 \mathrm{~cm}$ (mean $\pm \mathrm{SE})$; $n=9)$ than those with singles $(30 \pm 2.1 \mathrm{~cm} ; n=15)$. There were no significant effects of age nor age by number interactions. From day 5 an increasing number of chambers had been left by the beetles (Fig. 1), indicating depletion of the food.

Mean temperature at the stores was $19.7 \pm 1.44^{\circ} \mathrm{C}$ (range: $16.6-$ $22.8^{\circ} ; n=33$ ). Temperatures were not significantly affected by any other measured factor, e.g. depth or age. Dry weights of stored detritus were strongly affected by adhering sand. Hence, a better measure of potentially edible material was the amount of OM which was unaffected by sand. Fresh (i.e. 0-2 days old) food stores with one beetle contained $1.11 \pm 0.033 \mathrm{~g} \mathrm{OM}(n=5)$ and those with a pair of beetles $2.90 \pm 0.224 \mathrm{~g}(n=4)$.

Mean water content, expressed as \% dry weight of OM, was $114 \pm 10.5 \%(n=28)$ and ranged from 34 to $262 \%$ (Fig. 2$)$. There was a significant effect of age $(P=0.0185)$ on \% moisture with four very high values at 5-6 days (Fig. 2 ). If these were disregarded, the significant effect of store age disappeared $(P=0.15)$. The moisture of the sand surrounding the storage chambers was only $0.52 \pm 0.182 \%$.

\subsection{Ergosterol, $C: N$ ratio}

Ergosterol concentrations were highly variable, ranging from 24 to $530 \mu \mathrm{g} \mathrm{g}^{-1} \mathrm{OM}$, and averaging $229 \pm 28 \mu \mathrm{g}^{\mathrm{erg} o s t e r o l ~} \mathrm{~g}^{-1} \mathrm{OM}$, which corresponded to about $75 \mathrm{mg}$ fungal biomass $\mathrm{g}^{-1} \mathrm{OM}$. Ergosterol concentration tended to increase with increasing water

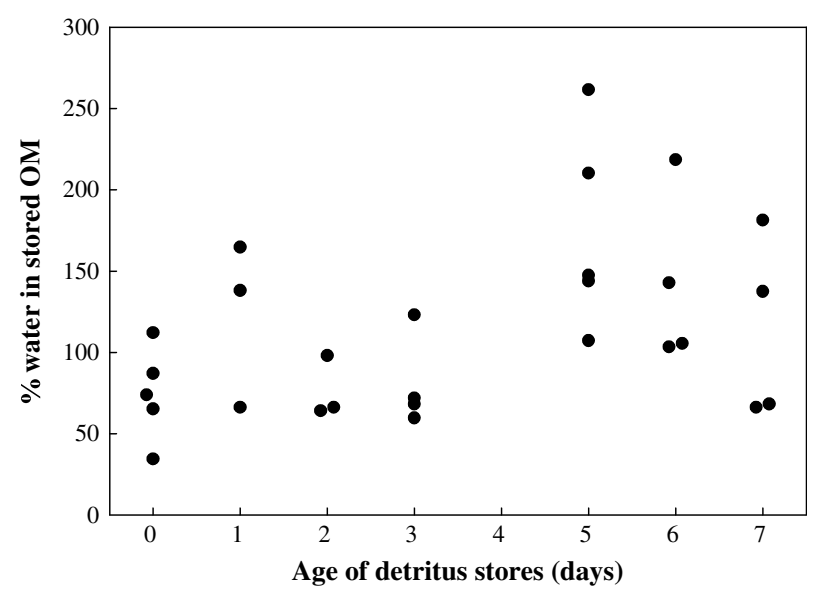

Fig. 2. Water content (\% of dry weight of the organic matter) of detritus stores in relation to their age. content $\left(E R G=-327+277 \times \log _{10}\left(\% \mathrm{H}_{2} \mathrm{O}\right) ; P=0.045\right)$, although explanatory power was low $\left(R^{2}=0.15\right)$. No significant relationship was found between ergosterol concentration and age of food stores. Thus, no fungal growth with increasing store age was indicated, which agreed with visual/olfactory observations.

Carbon to nitrogen ratios (atomic) averaged $34.7 \pm 0.86(n=27)$ and ranged from 26.4 to 43.3 . Only \% water had a significant effect on C:N ratios $(P=0.0012)$, which decreased slightly with increasing moisture.

\subsection{Changes of food stores over the feeding period; assimilation}

There were no 0-days-old eucalypt-free stores used with certainty by single beetles. But age-classes 1-2 days and 7 days each comprised five stores. From these, changes caused by singles over almost the entire feeding period could be estimated (Table 1 ). As about $60 \%$ of both $\mathrm{OM}, \mathrm{C}$ and $\mathrm{N}$ disappeared, the C: $\mathrm{N}$ ratio remained unchanged. Absolute losses of OM, C and N were 0.66, 0.376 and $0.0129 \mathrm{~g}$, respectively. Approximately $85 \%$ (0.064 g) of the initial fungal biomass was assimilated by beetles (Table 1 ). Assuming 50\% C and a C:N ratio of 15 for fungi (Kilham, 1994), this corresponds to 0.032 and $0.0021 \mathrm{~g}$ fungal $\mathrm{C}$ and $\mathrm{N}$, or 8.5 and $16.3 \%$ of the total losses of $\mathrm{C}$ and $\mathrm{N}$, respectively. Thus, $91.5 \%$ ( $0.344 \mathrm{~g})$ of the assimilated $\mathrm{C}$ and $83.7 \%(0.0108 \mathrm{~g})$ of the $\mathrm{N}$ must have come directly from plant detritus which also contributed about 0.66$0.064 \mathrm{~g}=0.596 \mathrm{~g}$ or $90 \%$ of the assimilated OM. In conclusion, most assimilation was from plant litter.

Initially, the total fungal biomass made up about $0.075 \mathrm{~g} \mathrm{OM}$ (Table 1), probably containing $0.0375 \mathrm{~g} \mathrm{C}$ and $0.0025 \mathrm{~g} \mathrm{~N}$. Thus, plant detritus itself amounted to $1.04 \mathrm{~g} \mathrm{OM}, 0.589 \mathrm{~g} \mathrm{C}$ and $0.0187 \mathrm{~g} \mathrm{~N}$. Fifty-seven percent (0.596/1.04), 58\% (0.344/0.589) and $58 \%(0.0108 / 0.0187)$ of the OM, C and N, respectively, in the plant litter was assimilated. The actual ingestion of the beetles remains unknown, but the detritus always included some coarse material that was not eaten. Hence, at least $60 \%$ of the ingested plant litter was probably assimilated.

\section{Discussion}

\subsection{Testing the hypotheses}

Hypothesis (1), that buried detritus would absorb water in the storage chambers, was not confirmed as there was no evidence of water uptake by, or evaporation from, the detritus during the 6-7 days of storage. Moreover, storage chambers were surrounded by dry ( $0.5 \%$ water) sand, and most were only at depths of $30-40 \mathrm{~cm}$, against $60-70 \mathrm{~cm}$ for $P$. striatum (Scholtz, 1989). The detritus did, however, contain $114 \%$ (w/w of the OM) water, presumably due to nocturnal fog condensation. A peak in the water content (Fig. 2) was probably caused by rare morning rain $(4 \mathrm{~mm})$ on October 7 .

Table 1

Mean $( \pm$ SE) attribute of stores.

\begin{tabular}{|c|c|c|c|}
\hline \multirow[t]{2}{*}{ Attribute } & \multicolumn{2}{|l|}{ Store age (days) } & \multirow{2}{*}{$\begin{array}{l}\% \text { Change from } \\
1-2 \text { to } 7 \text { days }\end{array}$} \\
\hline & $1-2(n=5)$ & $7(n=5)$ & \\
\hline$\overline{\mathrm{OM}}$ & $1.11 \mathrm{~g} \pm 0.033$ & $0.45 \mathrm{~g}$ & -60 \\
\hline Water & $0.95 \mathrm{~g} \pm 0.146$ & $0.47 \mathrm{~g}$ & -51 \\
\hline $\mathrm{C}$ & $0.626 \mathrm{~g} \pm 0.032$ & $0.250 \mathrm{~g}$ & -60 \\
\hline $\mathrm{N}$ & $0.0212 \mathrm{~g} \pm 0.00194$ & $0.00835 \mathrm{~g}$ & -61 \\
\hline Fungal biomass & $0.075 \mathrm{~g} \pm 0.0251$ & $0.011 \mathrm{~g}$ & -85 \\
\hline$C: N$ & $34.5 \pm 2.26$ & 34.9 & 1 \\
\hline
\end{tabular}

Initial and final properties of stores collected for feeding by single Pachysoma glentoni. SE not given for 7-days stores which had to be pooled into two larger samples ( 2 and 3 stores) for analysis. 
This wetted the detritus collected on that day and was still measurable in four stores harvested 5-6 days later.

Hypotheses (2) and (3) predicted vigorous fungal growth on the buried detritus, these fungi being the main food of $P$. glentoni. However, neither visual observations nor ergosterol measurements indicated any fungal growth. Also, the hypotheses are not confirmed if the lost $\mathrm{N}(0.013 \mathrm{~g})$ is accounted for by assuming that Pachysoma assimilated it from growing fungi and incorporated it in beetle tissue. The $\mathrm{N}$, and some assimilated $\mathrm{C}$ in tissues, would disappear when the beetle left, and additional $\mathrm{C}$ would be lost in respiration. Production of beetle tissue with $0.013 \mathrm{~g} \mathrm{~N}$ and a weightbased C:N ratio of 5 (Pokarzhevskii et al., 2003) would require assimilation of $0.2 \mathrm{~g}(0.013 \times 5 \times 3 \mathrm{~g})$ fungal $\mathrm{C}$, if production/ respiration is 0.5 . With the same production efficiency for $C$ (Deacon, 2006), fungal production of $0.2 \mathrm{~g}$ biomass-C would cost $0.4 \mathrm{~g}$ of respired C, i.e. a total loss of about $0.6 \mathrm{~g} \mathrm{C}, 96 \%$ of that initially present. Thus, respiratory carbon costs of the necessary fungal growth would exceed the measured $60 \%$ loss, indicating that the two hypotheses cannot be supported.

Which biological activity other than that of fungi might explain the loss of OM, C and N? Bacterial activity seems even less probable because of the dry conditions (Kilham, 1994), and no animals other than Pachysoma that might remove OM, e.g. termites, were observed. This leaves hypothesis (4) as the only likely possibility, i.e. that Pachysoma assimilation directly from plant litter caused the loss of $\mathrm{OM}, \mathrm{N}$ and $\mathrm{C}$.

\subsection{Assimilation and food of Pachysoma glentoni}

The results indicated that litter was eaten with an assimilation efficiency of about $60 \%$. Efficiencies in most terrestrial detritivores are lower; about 7\% for terrestrial caddis fly (Enoicyla pusilla) larvae (Van der Drift and Witkamp, 1959), 6\% for the millipede Glomeris marginata (David and Gillon, 2002) and 17-18\% for the isopods Porcellio scaber and Oniscus asellus (Hassall et al., 1987). These arthropods feed on temperate woodland litter. Compared to these animals, $P$. glentoni must have food of higher quality or/and a more efficient digestion.

The C:N ratio is a widely used index of the quality of OM as food/ substrate for heterotrophic organisms (Swift et al., 1979; Elser et al., 2000; Dorgelo and Leonards, 2001; Skov and Hartnoll, 2002). Quality should increase with decreasing C:N ratios until an optimum value of about 15-20. For the foliage of 406 terrestrial plant species, Elser et al. (2000) found a mean atomic C:N ratio of 36 . Thus, the food of P. glentoni, with a C:N ratio about 35 , should be of the same quality as the food available to many herbivores. Lower $\mathrm{C}: \mathrm{N}$ ratios in terrestrial litter are known, e.g. 23 (atomic) for ash litter (Bjørnlund and Christensen, 2005). Most values are, however, higher such as 45-50 for beech litter (Bjørnlund and Christensen, 2005), 46 for holm oak litter (main food of Glomeris in the Mediterranean region) (Gillon and David, 2001), 50-200 for wheat, rye, barley and oat straw (Christensen, 1987) and $56 \pm 3.0$ for eucalypt litter (this study) which was collected, but not eaten, by P. glentoni.

What explains the rather high quality of the detritus normally collected by $P$. glentoni? The remains of flowers, including seeds, produced during early spring constituted an important part of the surface litter in October. Several detritus-feeding Namib tenebrionids are known to prefer dead flowers as food (Crawford et al., 1990; Hanrahan and Seely, 1990). Also, one species (Onymacris plana) fed nara (Acanthosicyos horridus) flowers produced three times as many eggs day ${ }^{-1}$ and had a much higher lipid deposition than when fed with grass (Seely, 1983). The C:N ratio of nara flowers is only 13-19 (Klopatek and Stock, 1994), supporting the idea that a high proportion of flower remains may have enhanced the quality of the litter available to $P$. glentoni.

\subsection{Digestion and water}

Efficient digestion in P. glentoni might also explain the high assimilation rate. Similar rates in detritivorous arthropods, particularly millipedes and isopods (Wooten and Crawford, 1975; Kozlovskaja and Striganova, 1977) from deserts (Crawford, 1981) are ascribed to microbial degradation of structural plant carbohydrates such as cellulose and hemicelluloses in the guts (Kozlovskaja and Striganova, 1977; Taylor, 1982; Crawford and Taylor, 1984; Zimmer, 2002). Unfortunately, the digestive processes in P. glentoni are unknown, but the $60 \%$ assimilation rate is consistent with the view that desert food chains are physiologically highly efficient (Ayal, 2007).

P. glentoni has few opportunities for gaining water. Liquid water is unavailable during its strictly diurnal aboveground activity, leaving uptake by feeding and metabolic water as the likely possibilities. The approximately $0.5 \mathrm{~g}$ of water lost from the detritus (Table 1 ) is the only available estimate of the amount potentially extracted by feeding. Most of the assimilated $0.66 \mathrm{~g}$ OM was probably carbohydrate, yielding $0.56 \mathrm{~g}$ water per $\mathrm{g}$ metabolised food (Willmer et al., 2000). Lipids and proteins provide higher and lower water yields, respectively, but use of the carbohydrate factor for the entire assimilation suggests a production of about $0.4 \mathrm{~g}$ metabolic water. If so, the minimum-maximum range for total weekly water gain is $0.4-0.9 \mathrm{~g}$.

How does a large (4-5 g) beetle survive in an arid ecosystem with this modest water supply? The animals spend $95-98 \%$ of their time underground at a constant (Seely and Mitchell, 1987) and moderate temperature of about $20^{\circ} \mathrm{C}$. Apart from feeding, activity is probably low, and the flightless beetles have practically no wing muscles that must be metabolically maintained (Chown and Nicolson, 2004). Moreover, P. glentoni may, like its congeners $P$. striatum and $P$. gariepinum, have water-saving respiratory adaptations (Duncan and Byrne, 2005). All this may minimise water loss by respiration and cuticular evaporation.

\section{Conclusions}

Adult $P$. glentoni collect plant litter of relatively high quality, possibly due to a substantial proportion of flower remains. The beetles store and eat this material underground, assimilating no less than $60 \%$. During storage, no detectable fungal growth occurs, suggesting that most nutrition and water are provided by the litter and that fungi are unimportant food items.

In conclusion, the genus Pachysoma is a lineage of Scarabaeini which has successfully colonised desert ecosystems without the normal food of the tribe, i.e. wet dung of large herbivores. P. glentoni has achieved this by an unusual exploitation of plant litter, made possible by unique adaptations within the genus (Scholtz, 1989; Chown et al., 1998; Dacke et al., 2002; Scholtz et al., 2004; Duncan and Byrne, 2005) plus two general characteristics of Scarabaeini: (1) quick collection, relocation and burial of food, and (2) a largely underground life.

\section{Acknowledgements}

The financial support of P.H.'s and L.S.'s travel to and work in South Africa by the Carlsberg Foundation and the University of Copenhagen (P.H.) is gratefully acknowledged. Funding for C.H.S.'s research was provided by the South African National Research Foundation. We also thank the following from the Univ. of Copenhagen: K. Clemmensen and L. Christiansen for expert advice and assistance with ergosterol analyses, and $\mathrm{K}$. Heinsen for carrying out the $\mathrm{C}$ and $\mathrm{N}$ determinations. 


\section{References}

Ayal, Y., 2007. Review: trophic structure and the role of predation in shaping hot desert communities. Journal of Arid Environments 68, 171-187.

Bjørnlund, L., Christensen, S., 2005. How does litter quality and site heterogeneity interact on decomposer food webs of a semi-natural forest? Soil Biology and Biochemistry 37, 203-213.

Bouché, M.B., 1977. Stratégies lombriciennes. Ecological Bulletin (Stockholm) 25, $122-132$.

Chown, S.L., Pistorius, P., Scholtz, C.H., 1998. Morphological correlates of flightlessness in southern African Scarabaeinae (Coleoptera: Scarabaeidae): testing a condition of the water-conservation hypothesis. Canadian Journal of Zoology $76,1123-1133$.

Chown, S.L., Nicolson, S.W., 2004. Insect physiological ecology. Mechanisms and Patterns. Oxford University Press, Oxford, New York.

Christensen, B.T., 1987. Indledning. In: Christensen, B.T., Schiønning, P. (Eds.), Nedmuldning af halm. Statens Planteavlsforsøg. Beretning Nr. S 1911. Tidsskrift for Planteavls Specialserie, Copenhagen, pp. 9-21.

Clemmensen, K.E., Michelsen, A., Jonasson, S., Shaver, G.R., 2006. Increased ectomycorrhizal fungal abundance after long-term fertilization and warming of two arctic tundra ecosystems. New Phytologist 171, 391-404.

Crawford, C.S., 1981. Biology of Desert Invertebrates. Springer, Berlin, Heidelberg, New York.

Crawford, C.S., 1991. Animal adaptations and ecological processes in desert dunefields. Journal of Arid Environments 21, 245-260.

Crawford, C.S., Taylor, E.C., 1984. Decomposition in arid environments: role of the detritivore gut. South African Journal of Science 80, 170-176.

Crawford, C.S., Seely, M.K., 1987. Assemblages of surface-active arthropods in the Namib dunefield and associated habitats. Revue de Zoologie Africaine 101 397-421.

Crawford, C.S., Hanrahan, S.A., Seely, M.K., 1990. Scale-related habitat use by Physadesmia globosa (Coleoptera: Tenebrionidae) in a riparian desert environment. In: Seely, M.K. (Ed.), Namib Ecology: 25 Years of Namib Research. Transvaal Museum, Pretoria, pp. 135-142.

Dacke, M., Nordström, P., Scholtz, C.H., Warrant, E.J., 2002. A specialized dorsal rim for polarized light detection in the compound eye of the scarab beetle Pachysoma striatum. Journal of Comparative Physiology A 188, 211-216.

David, J.F., Gillon, D., 2002. Annual feeding rate of the millipede Glomeris marginata on holm oak (Quercus ilex) leaf litter under Mediterranean conditions. Pedobiologia 46, 45-52.

Deacon, J., 2006. In: Fungal Biology, fourth ed. Blackwell Publishing, Oxford.

Doblas-Miranda, E., Sánchez-Piñero, F., González-Megías, A., 2007. Soil macroinvertebrate fauna of a Mediterranean arid system: composition and temporal changes in the assemblage. Soil Biology and Biochemistry 39, 1916-1925.

Dorgelo, J., Leonards, P.E.G., 2001. Relationship between C/N ratio of food types and growth rate in the snail Potamopyrgus jenkinsi (E.A. Smith). Journal of the North American Benthological Society 20, 60-67.

Duncan, F.D., Byrne, M.J., 2005. The role of the mesothoracic spiracles in respiration in flighted and flightless dung beetles. Journal of Experimental Biology 208, 907-914.

Elser, J.J., Fagan, W.F., Denno, R.F., Dobberfuhl, D.R., Folarin, A., Huberty, A., Interlandi, S., Kilham, S.S., McCauley, E., Schulz, K.L., Siemann, E.H. Sterner, R.W., 2000. Nutritional constraints in terrestrial and freshwater food webs. Nature 408, 578-580.

Gillon, D., David, J.F., 2001. The use of near infrared reflectance spectroscopy to study chemical changes in the leaf litter consumed by saprophagous invertebrates. Soil Biology and Biochemistry 33, 2159-2161.

Hanrahan, S.A., Seely, M.K., 1990. Food and habitat use by three tenebrionid beetles (Coleoptera) in a riparian desert environment. In: Seely, M.K. (Ed.), Namib Ecology: 25 Years of Namib Research. Transvaal Museum, Pretoria, pp. 143-147.

Harrison, J.du G., Scholtz, C.H., Chown, S.L., 2003. A revision of the endemic southwestern African dung beetle subgenus Scarabaeus (Pachysoma) MacLeay, including notes on other flightless Scarabaeini (Scarabaeidae: Scarabaeinae). Journal of Natural History 37, 305-355.
Hassall, M., Turner, J.G., Rands, M.R.W., 1987. Effects of terrestrial isopods on the decomposition of woodland leaf litter. Oecologia 72, 597-604.

Holter, P., Scholtz, C.H., 2007. What do dung beetles eat? Ecological Entomology 32, 690-697.

Kilham, K., 1994. Soil Ecology. Cambridge University Press, Cambridge.

Klopatek, J.M., Stock, W.D., 1994. Partitioning of nutrients in Acanthosicyos horridus, a keystone endemic species in the Namib Desert. Journal of Arid Environments 26, 233-240.

Kozlovskaja, L.S., Striganova, B.R., 1977. Food, digestion and assimilation in desert woodlice and their relations to the soil microflora. Ecological Bulletin (Stockholm) 25, 240-245.

Louw, G.N., Seely, M.K., 1982. Ecology of Desert Organisms. Longman, London, New York.

Newell, S.Y., Arsuffi, T.L., Fallon, R.D., 1988. Fundamental procedures for determining ergosterol content of decaying plant material by liquid chromatography. Applied and Environmental Microbiology 54, 1876-1879.

Noy-Meir, I., 1974. Desert ecosystems: higher trophic levels. Annual Review of Ecology and Systematics 5, 195-214.

Pokarzhevskii, A.D., van Straalen, N.M., Zaboev, D.P., Zaitsev, A.S., 2003. Microbial links and element flows in nested detrital food-webs. Pedobiologia 47, 213-224.

Pollierer, M.M., Langel, R., Körner, C., Maraun, M., Scheu, S., 2007. The underestimated importance of belowground carbon input for forest soil animal food webs. Ecology Letters 10, 729-736.

Quinn, G.P., Keough, M.J., 2002. Experimental Design and Data Analysis for Biologists. Cambridge University Press, Cambridge.

Salmanowicz, B., Nylund, J.E., 1988. High performance liquid chromatography determination of ergosterol as a measure of ectomycorrhiza infection in Scots pine. European Journal of Forest Pathology 18, 291-298.

Scholtz, C.H., 1989. Unique foraging behaviour in Pachysoma (=Scarabaeus) striatum Castelnau (Coleoptera: Scarabaeidae): an adaptation to arid conditions? Journal of Arid Environments 16, 305-313.

Scholtz, C.H., Chown, S.L., 1995. The evolution of habitat use and diet in the Scarabaeoidea: a phylogenetic approach. In: Pakaluk, J., Slipinski, A. (Eds.), Biology, Phylogeny and Classification of Coleoptera. Papers Celebrating the 80th Birthday of Roy A. Crowson. Muzeum i Instytut Zoologii PAN, Warszawa, pp. 355-374.

Scholtz, C.H., Harrison, J.du G., Grebennikov, V.V., 2004. Dung beetle (Scarabaeus (Pachysoma)) biology and immature stages: reversal to ancestral states under desert conditions (Coleoptera: Scarabaeidae)? Biological Journal of the Linnean Society $83,453-460$.

Seely, M.K., 1979. Irregular fog as a water source for desert dune beetles. Oecologia 42, 213-227.

Seely, M.K., 1983. Effective use of the desert dune environment as illustrated by the Namib tenebrionids. In: Lebrun, H.M., André, H.M., De Medts, A., GrégoireWibo, C., Wauthy, G. (Eds.), New Trends in Soil Biology. Proceedings of the VIII International Colloquium of Soil Zoology. Dieu-Brichart, Ottignies-Louvain-LaNeuve, pp. 357-368.

Seely, M.K., Mitchell, D., 1987. Is the subsurface environment of the Namib Desert dunes a thermal haven for chthonic beetles? South African Journal of Zoology 22, 57-61.

Skov, M.W., Hartnoll, R.G., 2002. Paradoxical selective feeding on a low-nutrient diet: why do mangrove crabs eat leaves? Oecologia 131,1-7.

Swift, M.J., Heal, O.W., Anderson, J.M., 1979. Decomposition in Terrestrial Ecosystems. Blackwell Scientific Publications, Oxford, London, Edinburgh, Melbourne.

Taylor, E.C., 1982. Role of aerobic microbial populations in cellulose digestion by desert millipedes. Applied and Environmental Microbiology 44, 281-291.

Van der Drift, J., Witkamp, M., 1959. The significance of the breakdown of oak litter by Enoicyla pusilla Burm. Archives Néerlandaises de Zoologie 13, 486-492.

Willmer, P., Stone, G., Johnston, I., 2000. Environmental Physiology of Animals. Blackwell Science, Oxford.

Wooten, R.C., Crawford, C.S., 1975. Food, ingestion rates and assimilation in the desert millipede Orthoporus ornatus (Girard) (Diplopoda). Oecologia 20, 231-236.

Zimmer, M., 2002. Nutrition in terrestrial isopods (Isopoda: Oniscidea) an evolutionary-ecological approach. Biological Reviews 77, 455-493. 